\title{
DESIGN AND EVALUATION DIRECT SOLAR- DRYER TO DRY RED ONIONS SLICES
}

\author{
Hanafy W. M. * and Tarabye H. H. H. *
}

\begin{abstract}
An direct solar-electrical dryer has been designed and constructed at a Zagazig City of , Sharkia governorate, Egypt. Solar dryer consists of solar flat plate air collector with $V$-corrugated absorption plate in conecation with drying tray uint. The red onions most popular to consumer no dayes in the Zagazig City so that it was chosen to experiment. The new dryer prototype was tested its efficiency for drying red onions slices $5 \& 10 \mathrm{~mm}$ to study the effect of drying air velocities $(0.4,0.5$ and $0.6 \mathrm{~m} / \mathrm{s})$ at air temperature $(40.82,42.37$ and 43.81)respectiviely.The qualitative analysis for drying of onions slices 5 mm showed that initial moisture content of about $88 \%$ (wet basis) was reduced to final moisture content of about (10\%,12\% and 16\%) for velocities $(0.4,0.5$ and $0.6 \mathrm{~m} / \mathrm{s})$, while it were $(16 \%, 18 \%$ and $20.8 \%)$ for onions slices $10 \mathrm{~mm}$ respectiviely. The average percent of dryer efficiency was found to be 16.07, 12.83 and $12 \%$ for air speed $0.4,0.5$ and $0.6 \mathrm{~m} / \mathrm{s}$ respectiviely. In order to estimate and select the suitable form of solar drying curves, five different mathematical models, were compared according to their coefficient of determination $R^{2}, M B E, R M S E, \% E$ and chi square $X^{2}$ to estimate experimental drying curves. The page and Modified page II model in this condition proved to be the best for predicting drying behavior of red onions slices 5 and $10 \mathrm{~mm}$ with $\left(R^{2}=\right.$ 0.9961 and 0.9899) and $\left(X^{2}=0.000121\right.$ and 0.000423). The effective moisture diffusivity (Deff) was obtained using Fick's diffusion equation and its value varied from $1.46 \times 10^{-9}$ to $1.59 \times 10^{-9} \mathrm{~m}^{2} / \mathrm{s}$ and $5.25 \times 10^{-9}$ to $5.72 \times 10^{-9} \mathrm{~m}^{2} / \mathrm{s}$. The temperature dependence of the diffusivity coefficients was described with the activation energy (Ea) value of 21.33 $\mathrm{kJ} / \mathrm{mol}$ and $19.14 \mathrm{~kJ} / \mathrm{mol}$ for red onions slices 5 and 10mm. Finally an economic evaluation was calculated using the criterion of payback period which is found very small 1.84 years compared to the life of the dryer 25 years.
\end{abstract}

Key words: Solar drying, Drying models, Red Onions, Effective diffusivity, activation energy, efficiency, payback period.

*Lecturer, of Ag. Eng. Dept., Faculty of Agric.and Natural Resources, Aswuan University. 


\section{INTRODUCTION}


uring the last few years, drying onion, is one of the raw materials claiming great interest and demand, both in international and national markets as considered one of the most important as a vegetable crops. storing onions led to tendency to drying it using solar dryers as alternative sources to conserve the environment.

Lyes and Azeddine (2003) designed solar dryer for onion.The results showed that drying is affected by the surface of the collector, the air temperature and the product characteristics. Significant improvements were registered in the results, after the heater is added.

Drying is useful to preserve food quality and stability, lowering the water activity through the decrease of moisture content, and so avoiding spoilage and contamination during the storage period (Akpinar et al. 2006).

Pankaj and Sharma (2006) carried out some drying experiments on onion slices $(6 \mathrm{~mm}$ thickness) by using infrared convective drying. The average effective moisture diffusivity of onion slices ranged between $0.2514 \times 10^{-10}$ and $0.3233 \times 10^{-10} \mathrm{~m}^{2} / \mathrm{s}$ while the activation energy ranged between 5.06 and $10.63 \mathrm{~kJ} / \mathrm{mol}$ that indicated to decrease in energy of activation.

Sarsavadia (2006) Developed A solar-assisted forced convection dryer for drying of onion slices from initial moisture content of about $86 \%$ (wet basis) to final moisture content of about $7 \%$ (wet basis), the energy required per unit mass of water removed during without using recirculation of air was found between 23.548 and $62.117 \mathrm{MJ} / \mathrm{kg}$ water.

Mota et al.(2010) studied drying onions in terms of drying kinetics, which was evaluated at $30{ }^{\circ} \mathrm{C}, 50{ }^{\circ} \mathrm{C}$ and $60{ }^{\circ} \mathrm{C}$. The experimental data was tested with three empirical models (Newton, Modified Page and Logarithmic)all describe relatively well the dehydration kinetics at the three temperatures analysed. Moreover, from the experimental data it was possible to estimate the diffusivities, which range between $3.33 \times 10^{-9} \mathrm{~m}^{2} / \mathrm{s}$ at $30{ }^{\circ} \mathrm{C}$ and $8.55 \times 10^{-9} \mathrm{~m}^{2} / \mathrm{s}$ at $60{ }^{\circ} \mathrm{C}$.

El Mesery and Mwithiga (2012) investigated the drying behavior of onion slices by using two types of dryers, vertical and they found the Page model was the best in describing the drying behavior of onion slices and the 
drying time less in case of the horizontal convective comparison with vertical convective.

To obtain the highest solar intensity on the collector, in summer, the inclination angle of the reflector was maintained at $45^{\circ}$ with respect to the horizontal axis (Tabaei and Ameri, 2015).

Mahmoud et al.(2018) studied drying garlic slices in thin-layer with Infrared at $0.075,0.15,0.225$ and $0.3 \mathrm{~W} / \mathrm{cm} 2$ radiation intensity and 0.75 and $1.25 \mathrm{~m} / \mathrm{s}$ air flow velocity. The results showed increasing in drying rate and decreasing at the time of drying with decreasing air flow velocity and radiation intensity. The effective moisture diffusivity mean values ranged between $5.83 \times 1011$ and $7.66 \times 1010 \mathrm{~m}^{2} / \mathrm{s}$ for all investigated conditions.

\section{MATERIALS AND METHODS}

The drying process was conducted by using the direct solar dryer in late summer during the month of Sebtemper, 2018 in Zagazig City, Sharkia governorate, Egypt. (longitude $(\Phi)=30^{\circ} 34^{\prime} 00^{\prime \prime} \mathrm{N}$ and latitude $(\lambda)=31^{\circ}$ 30 ' $00^{\prime}$ " E). Onion slices drying by direct forced convection solarelectrical constructed and installed at at a the roof of house in Zagazig City of , Sharkia governorate, Egypt. Experiments started at 8:00 am and terminated at 5:00 pm. It was installed in an environment with the relative air humidity of 30 65\%, ambient air speed of $0.8 \sim 2.8 \mathrm{~m} / \mathrm{s}$ and ambient air temperature varying from 26 to $37^{\circ} \mathrm{C}$ under solar radiation changing between 100 and $782.4 \mathrm{~W} / \mathrm{m}^{2}$. During the experiments, the ambient temperature, relative humidity, and inlet and outlet temperatures of air in the solar collector and dryer chamber were recorded. dryer were installed on a raised far from the shade of buildings during the whole duration of the system trial. A schematic diagram of direct solar dryer used in the experiments is shown in Fig. (1). It was made from aluminum frame like box, sides and bottom were insulated by a layer of fiber glasses sandwiched between two parallel galvanized metal sheets with a thickness $0.025 \mathrm{~m}$ from the sides and $0.05 \mathrm{~m}$ from the bottom with walls of dimension $(1 \times 0.50 \times 0.30) \mathrm{m}$ (height, width and depth) The solar air dryer has an area of $0.5 \mathrm{~m}^{2}$ is inclined at an angle of $19^{\circ} 30^{\prime} 00^{\prime \prime} \mathrm{N}$ (latitude of Zagazig city) with the horizontal facing south all the time. Solar air dryer consists of three main parts it where:- 


\section{1- Corrugated plate solar collector:-}

Made from galvanized sheet thickness $0.001 \mathrm{~m}$ and $55^{\circ}$ goffer angle and height of $0.05 \mathrm{~m}$ from the basises of plate and painted matte black not shiny to absorb most of the incident solar radiation with an area of $0.35 \mathrm{~m}^{2}$.


Fig. (1): A Schematic view of direct solar dryer components.

2- Metal drawer:- the drawer dimension of $(0.30 \times 0.50 \times 0.30) \mathrm{m}$ (height, width and depth) the bottom of the drawer was removed and replaced with a wire mesh tray, to putting the product on it.

There is a distance of $0.20 \mathrm{~m}$ as air gap between the glasses cover and absorbing plate. The top losses are minimized by placing a glass cover of $0.005 \mathrm{~m}$ thickness over the top of the dryer.

3-Exhusted fan :- model SA6030 power in put 5 Watt, AC 220 to $240 \mathrm{~V}$, running at 2500 to $3100 \mathrm{rpm} /$ minute controlled manually by electrical resistance to change air velocity. 


\section{4- Sample preparation:-}

Locally available red onion was used in the present study procured from market. About $100 \mathrm{~g}$ of onion slices ( 5 and10 $\pm 0.025 \mathrm{~mm}$ ) were prepared by regulate the opening of the slicer knife with a vernier calliper.

\section{METHDOLOGY:-}

Red onion slices dryed by forced solar drying, in direct solar dryer, about $100 \mathrm{~g}$ of onions slices were uniformly distributed load tray and kept inside the dryer while $100 \mathrm{~g}$ of onions slices spread in the ground and left to natural drying by open sun-light.The initial moisture content of the onions slices were $88 \%(\mathrm{wb})$ and determined by using electric balance before and after drying. Three replicates about $100 \mathrm{~g}$ of onion slices were placed on electrical oven at $78^{\circ} \mathrm{C}$ for $24 \mathrm{~h}$ according to the Association of Official Analytical (AOAC, 2005). Ambient air enters the prototype from front opening under the suction electrical fan so that the air was drawn and hated between the glass and the absorber. The hot air pass through wire mesh tray which loaded by product then get out to surrounding. Three air velocity were studied $(0.4,0.5$ and $0.6 \mathrm{~m} / \mathrm{s})$. The samples mass were noted every 30 minute until the samples reached to final the percent of moisture ratio terminated the day 5.00:PM. Average temperature of the three trays were recorded at each fan speed. Moisture ratio (MR) was calculated from the obtained experimental moisture content values.

Moisture ratio:-It can be calculated as follows: (Midilli, 2001).

$$
\begin{array}{cl}
\mathrm{MR}= & \frac{(\mathrm{Mt}-\mathrm{Me})}{(\mathrm{Mo}-\mathrm{Me})}=\frac{\mathrm{Mt}}{\mathrm{Mo}} \longrightarrow(1) \\
\mathrm{MR} & \text { Moisture ratio } \\
\mathrm{Mt} & \text { Moisture content at time t, \%wb (wet base) or db (dry base) } \\
\mathrm{Mo} & \text { Initial moisture content, \%wb } \\
\mathrm{Me} & \text { Equilibrium Moisture, assume Me }=0
\end{array}
$$

Thin-layer drying models:- Table (1) showed the drying models tested with experimental drying data to find the most suitable for drying red onion slices. 
Table (1) Mathematical models describe the thin-layer drying curve.

\begin{tabular}{cclc}
\hline No. & Model name & Analytical expression & Reference \\
\hline 1 & Lewis & MR $=\exp \left(-\mathrm{k}_{\mathrm{L}} \mathrm{t}\right)$ & Bruce $(1985)$ \\
2 & Page & $\mathrm{MR}=\exp \left(-\mathrm{k}_{\mathrm{P}} \mathrm{t}^{\mathrm{n}}\right)$ & Page $(1949)$ \\
3 & Modified page & $\mathrm{MR}=\exp \left(-\mathrm{k}_{\mathrm{M}} \mathrm{t}\right)^{\mathrm{n}}$ & White et al. (1981) \\
4 & Modified page II & $\mathrm{MR}=\exp \left(-\mathrm{k}\left(\mathrm{t} / \mathrm{L}^{2}\right)^{\mathrm{n}}\right)$ & Diamante and Munro (1991) \\
5 & Henderson and Pabis & $\mathrm{MR}=\mathrm{a} \exp \left(-\mathrm{k}_{\mathrm{H}} \mathrm{t}\right)$ & Henderson and Pabis (1961) \\
\hline
\end{tabular}

The various constants in the tested models were determined using non linear regression procedure using IBM SPSS software package (IBM SPSS version 22). The coefficient of determination $\left(\mathrm{R}^{2}\right)$, reduced chisquare $\left(\mathrm{X}^{2}\right)$, root mean square error (RMSE) and the average percentage error $(\% \mathrm{E})$ were used to inspect the good fitness of the selected mathematical models to the experimental data. A model is considered more suitable the higher values of $\mathrm{R}^{2}$ and the lower the values of $\mathrm{X}^{2}$, RMSE and \%E (Midilli and Kucuk, 2003; Akpinar et al., 2006).

The following equations were used to calculate the above mentioned parameters:

$$
\begin{aligned}
& \mathrm{R}^{2}=1-\left[\begin{array}{ll}
\sum_{i=1}^{N} & \left(\mathrm{MR}_{\mathrm{Prd}}-\sum \mathrm{MR}_{\operatorname{Exp}}\right)^{2} \\
\hline \sum_{i=1}^{N} & \left.\overline{\left(\mathrm{MR}_{\mathrm{Prd}}\right.}-\sum \mathrm{MR}_{\operatorname{Exp}}\right)^{2}
\end{array} \longrightarrow\right. \text { (2) } \\
& \text { MR Prd predicted moisture ratio } \\
& \text { MR Exp experimental moisture ratio } \\
& \overline{\mathrm{MR}}_{\mathrm{Prd}} \quad \text { average predicted moisture ratio } \\
& x^{2}=\frac{\sum_{i=1}^{N}\left(\mathrm{MR}_{\operatorname{Exp}}-\mathrm{MR}_{\mathrm{Prd}}\right)^{2}}{N-n} \\
& N \quad \text { Number of observations } \\
& N \quad \text { Number of observations } \\
& \mathrm{RMSE}=\left[\begin{array}{cc}
\sum_{i=1}^{N}\left(\mathrm{MR}_{\operatorname{Prd}}-\sum \mathrm{MR}_{\mathrm{Exp}}\right)^{2} \\
N
\end{array}\right]^{1 / 2} \longrightarrow \\
& \% \mathrm{E}=\frac{100}{\mathrm{~N}} \sum \frac{\left|\mathrm{MR}_{\operatorname{Exp}}-\mathrm{MR}_{\operatorname{Prd}}\right|}{\mathrm{MR}_{\operatorname{Exp}}} \longrightarrow \text { (5) }
\end{aligned}
$$

\section{Moisture diffusivity and activation energy:-}

Eq.(6) calculated the effective moisture diffusivity coefficient by using Fick's second law from a slope of a straight line by plotting experimental drying data in terms of $\ln (\mathrm{MR})$ versus drying time(Crank, 1975). 


$$
\begin{aligned}
& \mathrm{MR}=\frac{\mathrm{Mt}}{\mathrm{Mo}}=\frac{8}{\pi^{2}} \exp \left[\frac{\pi^{2} \mathrm{D}_{\mathrm{eff}} \mathrm{t}}{4 \mathrm{~L}^{2}}\right] \longrightarrow(6) \\
& \text { Deff } \quad \text { Effective diffusivity, } \mathrm{m}^{2} / \mathrm{s} \\
& \text { L Thickness of the samples (m) } \\
& \mathrm{T} \quad \text { Drying time (min) }
\end{aligned}
$$

The effective moisture diffusivity can be related with temperature by simple Arrhenius-type relationship:
$\mathrm{D}_{\text {eff }}=\mathrm{D}_{\mathrm{o}} \exp$
$\left[-\frac{\mathrm{Ea}}{\mathrm{R} \mathrm{T}_{\mathrm{abs}}}\right]$
$\mathrm{Ea}$
Activation energy
$\mathrm{D}_{\mathrm{o}}$
Pre-exponential factor of Arrhenius equation $\left(\mathrm{m}^{2} / \mathrm{s}\right)$.
$\mathrm{R}$ Universal gas constant $(8.3143) \mathrm{kJ} /(\mathrm{kmol} . \mathrm{K})$
Tabs Absolute air temperature $(\mathrm{K})$

\section{Solar collector \& dryer calculation:-}

1- The thermal collector efficiency $\left(\% \mathbf{\eta}_{\mathrm{C}}\right)$ :- collector efficiency is defined as the ratio of energy output of the collector to energy input (R. Ac) to the collector (J) and is calculated from the following mathematical formula (Boughali et al.2009).

$$
\begin{aligned}
\% \mathrm{n}_{\mathrm{c}}= & \mathrm{m} \cdot \mathrm{Cp} \cdot \Delta \mathrm{T} \\
\mathrm{M} & \text { Rad. Ac } \\
\mathrm{M} & \text { mass flow rate of air }(\mathrm{kg} / \mathrm{s}) \\
\mathrm{Cp} & \text { specific heat of air } 1007\left(\mathrm{~J} / \mathrm{kg} \cdot{ }^{\circ} \mathrm{c}\right) \\
\mathrm{Rad} & \text { solar radiation }\left(\mathrm{W} / \mathrm{m}^{2}\right) \\
\mathrm{Ac} & \text { absorbent area }\left(\mathrm{m}^{2}\right) \\
\Delta \mathrm{T} & \text { difference output and input air temperatures }\left({ }^{\circ} \mathrm{c}\right)
\end{aligned}
$$

The dryer efficiency $\left(\% \eta_{d}\right)$ : - Expressed by the ratio of energy used to evaporate water in the product to the energy provide to the air during drying plus energy of the fan (EF) in the following form (Boughali et al.2009):

$$
\% \eta_{d}=\frac{\text { me } * \text { Le }}{\text { Rad At }+E_{F}} \times 100 \longrightarrow(9)
$$


Le latent-heat of vaporization of moisture $(\mathrm{kJ} / \mathrm{kg})$

A $\quad$ area $\left(\mathrm{m}^{2}\right)$

EF energy of the fan $(J)$

\section{Costs was calculated according to the following model:-}

Based on the climatic conditions in Zagazig City which allow using the solar-electrical dryer almost all the year days (365 days).The costs and the main economic parameters based on the economic situation in Egypt are shown in Table (2).

Table (2)Payback period of the solar-electrical dryer.

\begin{tabular}{l|c}
\hline Cost of Cost of dryer & $3000 \mathrm{L.E}$ \\
Capacity of dryer & $0.5 \mathrm{~kg}$ \\
Depreciation & $300 \mathrm{L.E}$ \\
Life of dryer & 25 years \\
Cost of maintenance & $200 \mathrm{~L} . \mathrm{E}$ \\
Labor cost $5 \times 360$ year & $900 \mathrm{L.E}$ \\
Cost of electrical consumption, L.E /year & $32 \mathrm{L.E}$ \\
Cost of raw onions $3 \times 0.5 \times 360$ & $540 \mathrm{L.E}$ \\
\hline Total cost & $1972 \mathrm{L.E}$ \\
\hline Total income $360 \times 0.1 \times 100$ & $3600 \mathrm{~L} . \mathrm{E}$ \\
\hline Net income & $1628 \mathrm{~L} . \mathrm{E}$ \\
\hline Note 1 US Dollar $\approx 18 \mathrm{L.E}$. & \\
\hline
\end{tabular}

Using this data, the payback period was calculated using the formula below (Neufville, 1990)

Payback period $=\frac{\text { Initial Investment }}{\text { Annual Net Undiscounted Benefits }}$

The payback period is determined as the time required for the investment cost to equal the return.

\section{5-Rehydration ratio and coefficient of rehydration:}

The rehydration ratio was estimated by placing $10 \mathrm{~g}$ of samples with 1000 $\mathrm{ml}$ of boiling water about 5 minutes (Maskan ,2001).

$$
\begin{aligned}
& \mathrm{Rr}=\frac{\mathrm{W}_{\mathrm{r}}}{\mathrm{W}_{\mathrm{d}}} \longrightarrow \text { (11) } \\
& \mathrm{R}_{\mathrm{r}} \quad \text { Rehydration ratio } \\
& \mathrm{Wr} \quad \text { weight of rehydrated sample, g. } \\
& \mathrm{Wd} \quad \text { weight of dry sample, } \mathrm{g} \text {. } \\
& \mathrm{COR}=\frac{\mathrm{W}_{\mathrm{r}}\left(100-\mathrm{M}_{\mathrm{i}}\right)}{\mathrm{W}_{\mathrm{d}}\left(100-\mathrm{M}_{\mathrm{f}}\right)} \longrightarrow \text { (12) }
\end{aligned}
$$


COR Coefficient of rehydration.

Mi Moisture content of samples before dehydration, \% (wb)

\section{Measuring Instrumentations.}

Weather station model PC-200:- Was used for monitoring solar radiation $\left(1 \sim 2000 \mathrm{~W} / \mathrm{m}^{2}\right)$ with accuracy of $\pm 5 \%$.

Digital thermometer model (TPM-10):-series hand held instrument with a thermocouple was used for monitoring temperature with accuracy of $\pm 1^{\circ} \mathrm{C}$ and at range $\left(-50 \sim 110^{\circ} \mathrm{C}\right)$ by reading liquid crystal display (LCD).

Digital anemometer model (GM816):- series hand held Instrument used for measuring wind speed \& temperature by reading liquid crystal display. Wind speed range $(0 \sim 30 \mathrm{~m} / \mathrm{s})$.

Digital hygrometer-thermometer model (ETI 810-155):- series hand held Instrument. With a thermocouple was used for monitoring relative humidity at range (20 - $99 \%)$ with accuracy of $\pm 5 \%$.

Electronic balance model (SF-400): -having an accuracy of $0.01 \mathrm{~g}$ with capacity $7 \mathrm{~kg}$ and the weight of samples were recorded on a LCD display. Vernier caliper: - having a least count $0.025 \mathrm{~mm}$.

\section{RESULTS AND DISCUSSION}

\section{Practical trial for solar-electrical dryer under load.}

Designing and evaluation a thermal behavior of the direct solar-electrical dryer requirmentes knowledge an important parameter such as adata on the ambient air temperature, air speed, humidity of ambient air and solar radiation.

Figs. (2-4) showed the trial run for three days under three air velocity indicated that the maximum temperatureis achieved afternoon while the maximum radiation is reached at 12 noon. The moisture decrease inside the dryer.The diffreance between ambient air and input dryer temperature were $\left(2.6 \sim 30.7^{\circ} \mathrm{c}\right),\left(2.7 \sim 33.4^{\circ} \mathrm{c}\right)$ and $\left(2.5 \sim 34.9^{\circ} \mathrm{c}\right)$ for air speed $0.4,0.5$ and $0.6 \mathrm{~m} / \mathrm{s}$ on the practical trial as they depending on weather factors.Its noticed that increased air velocity decreased the dryer temperature. 


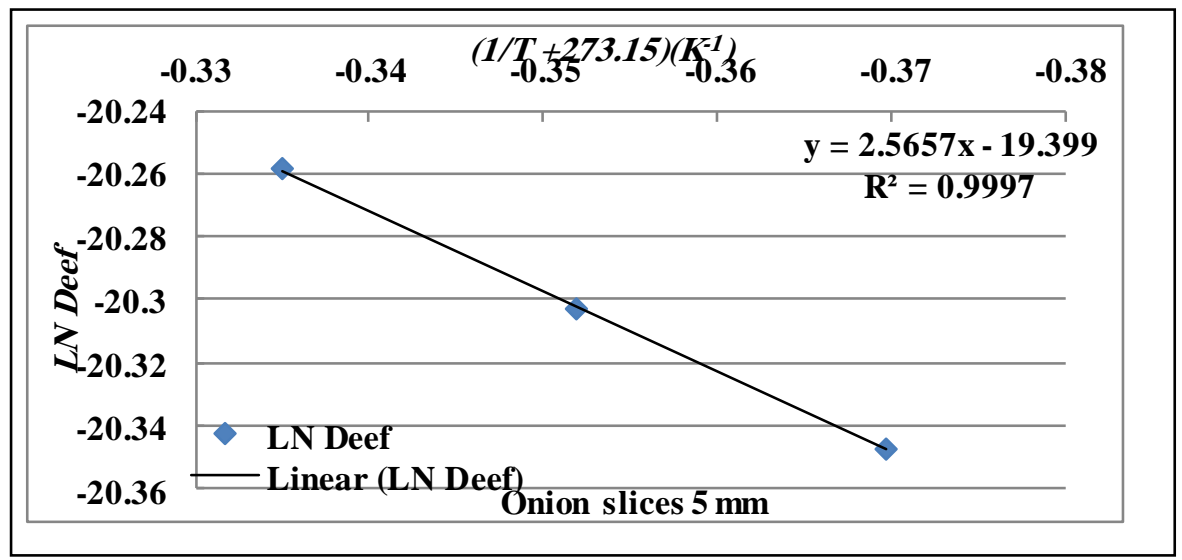

Fig. (2): Solar radiation and temperature variation of different elements of the collector on 19/9/2018.



Fig. (3): Solar radiation and temperature variation of different elements of the collector on 20/9/2018.

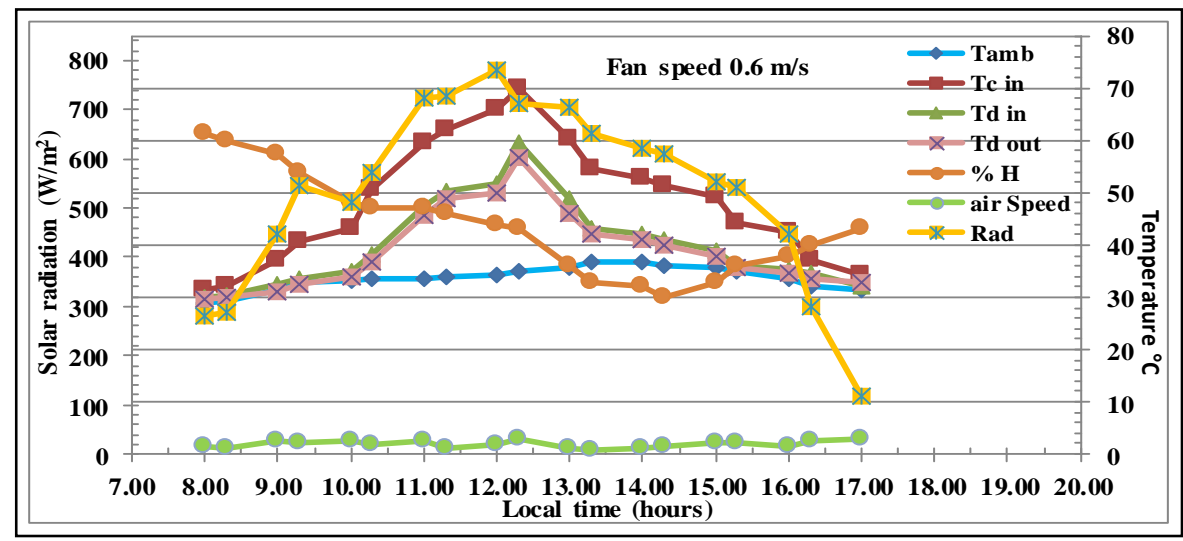

Fig. (4): Solar radiation and temperature variation of different elements of the collector on 21/9/2018. 


\section{Collector efficiency $(\% \eta)$ :-}

Figure (5). Pointing to the collector efficiency which increases with solar radiation increase until a limit where the efficiency tends to come down beyond this value. From the linear relationship between the velocity of air masse flow rate and the passage of local time,it observed that collector efficiency increases, rapidly at hight velocities $3 \mathrm{~m} / \mathrm{s}$, collector efficiency increases with solar radiation increase until a limit where the efficiency tends to come down beyond this value and they were ranged from (14.86\% to $43.42 \%),(15.23 \%$ to $59.41 \%)$ and $(14.07 \%$ to $73.43 \%)$ at air speed $0.4,0.5$ and $0.6 \mathrm{~m} / \mathrm{s}$ respectively so that velocities $0.6 \mathrm{~m} / \mathrm{s}$ is better comparing with the others velocities. (Kutscher et al.1993) noted that efficiency increase until for approach velocities greater than $5 \mathrm{~m} / \mathrm{s}$ then it constant beyond this value so our results agreement with previously studies.

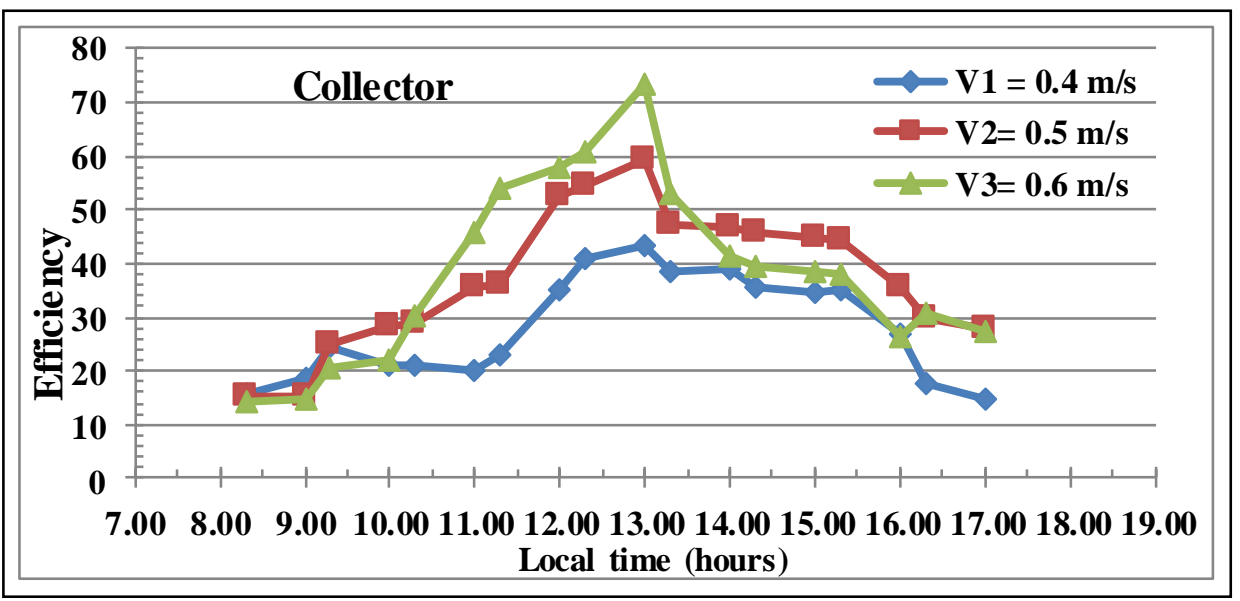

Fig. (5): Daily collector efficiency versus velocity and local time. Dryer efficiency $(\% \eta)$ : -

The daily dryer efficiency given in Fig. (6) and it were ranged from $(3.27 \%$ to $30.62 \%),(1.43 \%$ to $39.04 \%)$ and $(0.39 \%$ to $44.25 \%)$ at air speed $0.4,0.5$ and $0.6 \mathrm{~m} / \mathrm{s}$ respectively. It observed the system dryer efficiency for air speed $0.4 \mathrm{~m} / \mathrm{s}$ higher comparatively to other velocities. There is a seasonal variation in the climatic parameters of ambient air and the solar radiation so that the average efficiency of is not uniform and are 
often ranged from 1.7 to $37.97 \%$. The thermal efficiency is higher on the first hours of drying because the presence of moisture near to the surface of the product; then decreased continuously until the end of drying because the moisture content of the product is also decreased; so that it required more energy to drive out the same amount of moisture from the product.

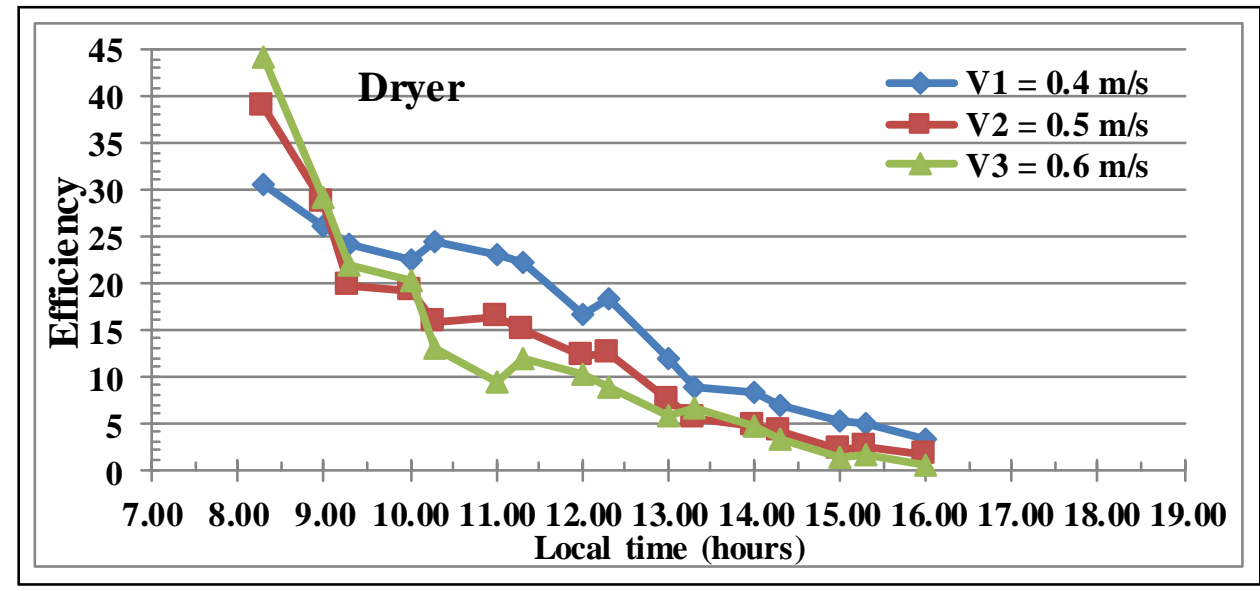

Fig. (6): Daily collector efficiency versus velocity and local time.

Effect of temperature and velocity on moisture content of red onion slices:Fig.(7) present relation between moisture ratio and drying time for three air speed rates were $0.4,0.5$ and $0.6 \mathrm{~m} / \mathrm{s}$ and control respectively.


Fig. (7): Effect of temperature and velocity on red onions slices $5 \&$ $10 \mathrm{~mm}$ drying of various times. 
The moisture ration differed with the air speed rates in the dryer. This difference can be explained by decreasing air temperature from 43.81, 42.37and 40.82 for air speed $0.4,0.5$ and $0.6 \mathrm{~m} / \mathrm{s}$ depending on the climatic conditions in the experiment day. So that increasing air temperature decreased significantly the moisture ratio from $(11.11,13.63$ $\& 16.27 \% \mathrm{db}$ ) for onion slices $5 \mathrm{~mm}$ while it were $(19.04 \%, 21.95 \%$ \& $26.26 \% \mathrm{db}$ ) Also an increase in air velocity from 0.4 to $0.6 \mathrm{~m} / \mathrm{s}$ increases moisture ratio due to surface drought phenomenon. From the energy point of view it is preferable in drying operation to use low airflow rate which decreased significantly the moisture ratio (Boughali et al 2009)

\section{Drying rate of sliced red onions slices $5 \& 10$ mm:-}

In our experimental conditions, the samples show that drying rate took place only in the falling rate period and no constant stage was observed in drying curves Fig. (8).
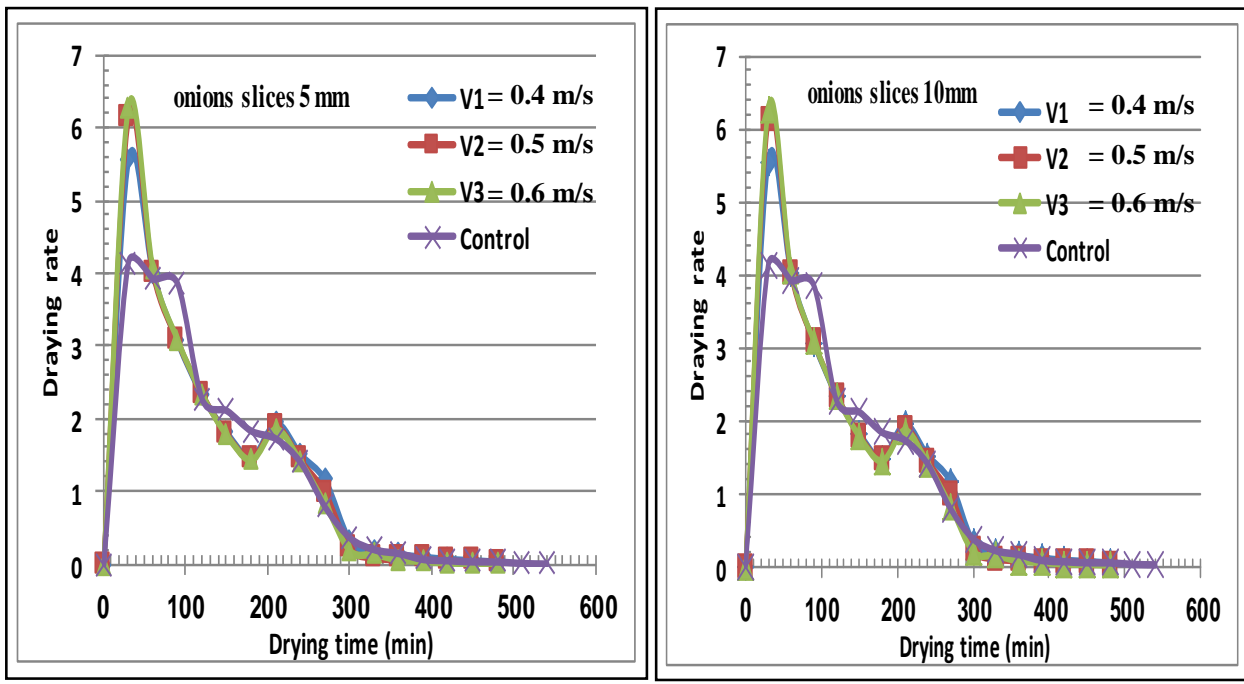

Fig. (8): Effect of drying rate for onions slices $5 \& 10 \mathrm{~mm}$ drying of various times at velocity $0.4,0.5$ and $0.6 \mathrm{~m} / \mathrm{s}$.

When the temperature inside the dryer increases the drying rate well be higher compared to the open sun drying. The drying rate gradually reduces in the later period. There was two drying period found from the results called falling rate period. For the first falling period, drying rate is very fast due to the large difference in the moisture content of onion slices and dry air. The second d falling period, the rate of drying is slow as moisture gradient of onions slice and outside air is reduced. The results 
showed that the higher drying rate accompanying with air flow rate 0.6 $\mathrm{m} / \mathrm{s}$ compering with the other velocities in the first drying stage while it decreased in the second stage. This implied meaning that a film of water did not exist at the surface of the crop and moisture transfer from the interior of the product to its surface is effectuated by several complicated mechanisms (liquid or vapor diffusion or capillary forces), due to high dehydration in the product surface which making difficulty in liquid diffusion in the second stage. These results are in agreement with the observations of some researchers. (Kolawole et al., 2007).

\section{Fitting model for describing drying process:-}

The obtained statistical parameters for data fitting for the 5 mathematical models of drying onions slices at various temperatures and air speed are presented in table (3-5). All approximate models were calculated using SPSS and MS Excel. The best is the one which has a maximum $\mathrm{R}^{2}$ and a minimum $\mathrm{x}^{2}$.The five models revealed high values of $\mathrm{R}^{2}$ onion slices 5 $\mathrm{mm}$ ranged from (0.9968 to 0.9940$),(0.9963$ to 0.9798$)$ and $(0.9927$ to 0.9694 ) while onion slices $10 \mathrm{~mm}$ ranged from (0.9876 to 0.9682$)$, (0.9818 to 0.9463$)$ and $(0.9867 \& 0.9797)$ for air speed rates $0.4,0.5$ and $0.6 \mathrm{~m} / \mathrm{s}$ respectively. Accordingly, all tested models for onions slices 5 $\mathrm{mm}$ Page and Modified page II models displayed the highest average value of $\mathrm{R}^{2}$ and the lowest values of $\mathrm{X}^{2}, \mathrm{RMSE}$ and $\% \mathrm{E}$ for fan speed while onions slices $10 \mathrm{~mm}$ page, Modified page II for air speed rates 0.4 , 0.5 and $0.6 \mathrm{~m} / \mathrm{s}$ respectively. Consequently, this model is the best one among the tested models that accurately express the thin layer drying behavior of onion slices under the studied conditions.

\section{Calculation of effective moisture diffusivity ( $D_{\text {eff }}$ :-}

The determined values of effective moisture diffusion coefficient $\left(D_{\text {eff }}\right)$ for all the drying temperatures calculated by the Eq.(7) according to the slope which was obtained by the linear fitting, which are presented in Figure (9).

$$
\text { Slope }=\frac{\pi^{2} D_{\text {eff }}}{4 \mathrm{~L}^{2}} \longrightarrow
$$

The values of effective moisture diffusion coefficient are shown in Table (5); it can be observed that the $D_{\text {eff }}$ of red onions slices $5 \mathrm{~mm}$ varied from $1.46 \times 10^{-9}$ to $1.59 \times 10^{-9} \mathrm{~m}^{2} / \mathrm{s}$ in the range of temperatures from 40.82 to $43.81{ }^{\circ} \mathrm{C}$, while it were varied from $5.25 \times 10^{-9}$ to $5.72 \times 10^{-9} \mathrm{~m}^{2} / \mathrm{s}$ of red onions slices $10 \mathrm{~mm}$ which suggests an increase of $D_{\text {eff }}$ with the 
Table (3) Statistical result of drying models for onions slices $5 \mathrm{~mm}$ at air speed $(0.4,0.5 \& 0.6 \mathrm{~m} / \mathrm{s})$ and sundry.

\begin{tabular}{|c|c|c|c|c|c|c|c|c|c|c|}
\hline \multirow{2}{*}{ Model } & \multirow{2}{*}{ Tray no. } & \multirow{2}{*}{ Thickness } & \multicolumn{3}{|c|}{ Constants } & \multicolumn{5}{|c|}{ Determination Statistical Coefficient } \\
\hline & & & $\mathbf{k}$ & $\mathbf{N}$ & $\mathbf{a}$ & $\mathbf{R}^{2}$ & $\mathbf{X}^{2}$ & MBE & RMS & $\% \mathbf{E}$ \\
\hline \multirow{4}{*}{ Lewis } & $\mathbf{T}_{1}$ & $5 \mathrm{~mm}$ & -0.009416 & - & - & 0.994900 & 0.003093 & 0.036997 & 0.053731 & -1.067929303 \\
\hline & $\mathbf{T}_{2}$ & $5 \mathrm{~mm}$ & -0.009006 & - & - & 0.979800 & 0.006588 & 0.059724 & 0.078412 & -1.825417505 \\
\hline & $\mathbf{T}_{3}$ & $5 \mathrm{~mm}$ & -0.008616 & - & & 0.969400 & 0.009054 & 0.071256 & 0.091924 & -2.191694965 \\
\hline & $\mathbf{T}_{\text {atmo. }}$ & $5 \mathrm{~mm}$ & -0.006625 & - & - & 0.931100 & 0.015827 & 0.097437 & 0.122260 & -2.657199101 \\
\hline \multirow{4}{*}{ Page } & $\mathbf{T}_{1}$ & $5 \mathrm{~mm}$ & 0.022541 & 0.859857 & - & 0.996800 & 0.000121 & -0.000368 & 0.011597 & 0.010636748 \\
\hline & $\mathbf{T}_{2}$ & $5 \mathrm{~mm}$ & 0.027837 & 0.827641 & - & 0.996300 & 0.000155 & 0.001723 & 0.010249 & -0.052648205 \\
\hline & $\mathbf{T}_{3}$ & $5 \mathrm{~mm}$ & 0.031777 & 0.801894 & - & 0.992700 & 0.000150 & 0.001945 & 0.011386 & -0.059828766 \\
\hline & T atmo. & $5 \mathrm{~mm}$ & 0.033918 & 0.765280 & - & 0.977300 & 0.000442 & 0.003128 & 0.019817 & -0.085303211 \\
\hline \multirow{4}{*}{ Modified page } & $\mathbf{T}_{1}$ & $5 \mathrm{~mm}$ & 0.012149 & 0.859857 & - & 0.996800 & 0.000121 & -0.000368 & 0.011597 & 0.010636748 \\
\hline & $\mathbf{T}_{2}$ & $5 \mathrm{~mm}$ & 0.013204 & 0.827641 & - & 0.996300 & 0.000155 & 0.001723 & 0.010249 & -0.052648205 \\
\hline & $\mathbf{T}_{3}$ & $5 \mathrm{~mm}$ & 0.013554 & 0.801894 & - & 0.992700 & 0.000150 & 0.001945 & 0.011386 & -0.059828766 \\
\hline & T atmo. & $5 \mathrm{~mm}$ & 0.012014 & 0.765280 & - & 0.977300 & 0.000313 & 0.003468 & 0.016679 & -0.085303211 \\
\hline \multirow{4}{*}{ Modified page II } & $\mathbf{T}_{1}$ & $5 \mathrm{~mm}$ & 0.358940 & 0.859857 & - & 0.996800 & 0.000121 & -0.000374 & 0.011597 & 0.010801364 \\
\hline & $\mathbf{T}_{2}$ & $5 \mathrm{~mm}$ & 0.393215 & 0.829814 & - & 0.996300 & 0.000148 & 0.004255 & 0.011325 & -0.130064881 \\
\hline & $\mathbf{T}_{3}$ & $5 \mathrm{~mm}$ & 0.419874 & 0.801894 & - & 0.992700 & 0.000150 & 0.001945 & 0.011386 & -0.059812076 \\
\hline & T atmo. & $5 \mathrm{~mm}$ & 0.398320 & 0.765280 & - & 0.977300 & 0.000442 & 0.003137 & 0.019819 & -0.085541103 \\
\hline \multirow{4}{*}{$\begin{array}{c}\text { Henderson and } \\
\text { Pabis }\end{array}$} & $\mathbf{T}_{1}$ & $5 \mathrm{~mm}$ & -0.009000 & - & 0.8275 & 0.984000 & 0.002764 & -0.005309 & 0.048942 & 0.026382613 \\
\hline & $\mathbf{T}_{2}$ & $5 \mathrm{~mm}$ & -0.009000 & - & 0.7117 & 0.984000 & 0.007499 & -0.005309 & 0.080617 & 0.619532942 \\
\hline & $\mathbf{T}_{3}$ & $5 \mathrm{~mm}$ & -0.009000 & - & 0.671 & 0.969400 & 0.009820 & -0.005309 & 0.092252 & 0.92914112 \\
\hline & T atmo. & $5 \mathrm{~mm}$ & -0.007000 & - & 0.577900 & 0.931100 & 0.014605 & -0.037354 & 0.113938 & 1.018689654 \\
\hline
\end{tabular}


Table (4) Statistical result of drying models for onions slices $10 \mathrm{~mm}$ at air speed $(0.4,0.5 \& 0.6 \mathrm{~m} / \mathrm{s})$ and sundry.

\begin{tabular}{|c|c|c|c|c|c|c|c|c|c|c|}
\hline \multirow{2}{*}{ Model } & \multirow{2}{*}{ Tray no. } & \multirow{2}{*}{ Thickness } & \multicolumn{3}{|c|}{ Constants } & \multicolumn{5}{|c|}{ Determination Statistical Coefficient } \\
\hline & & & $\mathbf{k}$ & $\mathbf{n}$ & $\mathbf{a}$ & $\mathbf{R}^{2}$ & $\mathbf{X}^{2}$ & MBE & RMS & $\% \mathbf{E}$ \\
\hline \multirow{4}{*}{ Lewis } & $\mathbf{T}_{1}$ & $10 \mathrm{~mm}$ & -0.008463 & - & - & 0.968200 & 0.000434 & -0.005718 & 0.020161 & 0.022906234 \\
\hline & $\mathbf{T}_{2}$ & $10 \mathrm{~mm}$ & -0.008149 & - & - & 0.946300 & 0.000786 & 0.019348 & 0.027144 & -0.457511824 \\
\hline & $\mathbf{T}_{3}$ & $10 \mathrm{~mm}$ & -0.007759 & - & & 0.935600 & 0.001667 & 0.032024 & $\mathbf{0 . 0 3 9 5 3 3}$ & -0.760437832 \\
\hline & $\mathbf{T}_{\text {atmo. }}$ & $10 \mathrm{~mm}$ & -0.005766 & - & - & 0.910200 & 0.005321 & 0.056666 & 0.070892 & -1.124224503 \\
\hline \multirow{4}{*}{ Page } & $\mathbf{T}_{1}$ & $10 \mathrm{~mm}$ & 0.007549 & 1.023123 & - & 0.987600 & 0.000423 & -0.001853 & 0.019245 & 0.041952343 \\
\hline & $\mathbf{T}_{2}$ & $10 \mathrm{~mm}$ & 0.010252 & 0.972670 & - & 0.981800 & 0.000439 & -0.001003 & 0.019604 & 0.023706866 \\
\hline & $\mathbf{T}_{3}$ & $10 \mathrm{~mm}$ & 0.011907 & 0.943489 & - & 0.979700 & 0.000429 & -0.000183 & 0.019365 & 0.004344695 \\
\hline & T atmo. & $10 \mathrm{~mm}$ & 0.008245 & 0.969923 & - & 0.969900 & 0.000955 & 0.006618 & 0.029136 & -0.131301432 \\
\hline \multirow{4}{*}{ Modified page } & $\mathbf{T}_{1}$ & $10 \mathrm{~mm}$ & 0.008430 & 1.023123 & - & 0.987600 & 0.000842 & -0.000644 & 0.027364 & 0.041952343 \\
\hline & $\mathbf{T}_{2}$ & $10 \mathrm{~mm}$ & 0.009014 & 0.972670 & - & 0.981800 & 0.000439 & -0.001003 & 0.019604 & 0.023706866 \\
\hline & $\mathbf{T}_{3}$ & $10 \mathrm{~mm}$ & 0.009132 & 0.943489 & - & 0.979700 & 0.000429 & -0.000183 & 0.019365 & 0.004344695 \\
\hline & T atmo. & $10 \mathrm{~mm}$ & 0.007105 & 0.969923 & - & 0.969900 & 0.000955 & 0.006618 & 0.029136 & -0.131301432 \\
\hline \multirow{4}{*}{ Modified page II } & $\mathbf{T}_{1}$ & $10 \mathrm{~mm}$ & 0.839709 & 1.023123 & - & 0.987600 & 0.000423 & -0.001862 & 0.019248 & 0.042169821 \\
\hline & $\mathbf{T}_{2}$ & $10 \mathrm{~mm}$ & 0.903933 & 0.972670 & - & 0.981800 & 0.000439 & -0.001000 & 0.019604 & 0.02363964 \\
\hline & $\mathbf{T}_{3}$ & $10 \mathrm{~mm}$ & 0.917870 & 0.943489 & - & 0.979700 & 0.000429 & -0.000177 & 0.019364 & 0.004199119 \\
\hline & T atmo. & $10 \mathrm{~mm}$ & 0.717846 & 0.969923 & - & 0.969700 & 0.000955 & 0.006609 & 0.029131 & -0.131115826 \\
\hline \multirow{4}{*}{$\begin{array}{c}\text { Henderson and } \\
\text { Pabis }\end{array}$} & $\mathbf{T}_{1}$ & $10 \mathrm{~mm}$ & -0.008000 & - & 0.9594 & 0.968200 & 0.000686 & 0.000231 & 0.024506 & -0.005236397 \\
\hline & $\mathbf{T}_{2}$ & $10 \mathrm{~mm}$ & -0.008000 & - & 0.8595 & 0.946300 & 0.002670 & -0.016804 & 0.048330 & 0.397368424 \\
\hline & $\mathbf{T}_{3}$ & $10 \mathrm{~mm}$ & -0.008000 & - & 0.8124 & 0.935600 & 0.004501 & -0.029261 & 0.062754 & 0.694830778 \\
\hline & T atmo. & $10 \mathrm{~mm}$ & -0.006000 & - & 0.748100 & 0.910200 & 0.009230 & -0.035978 & 0.090578 & 0.713785238 \\
\hline
\end{tabular}




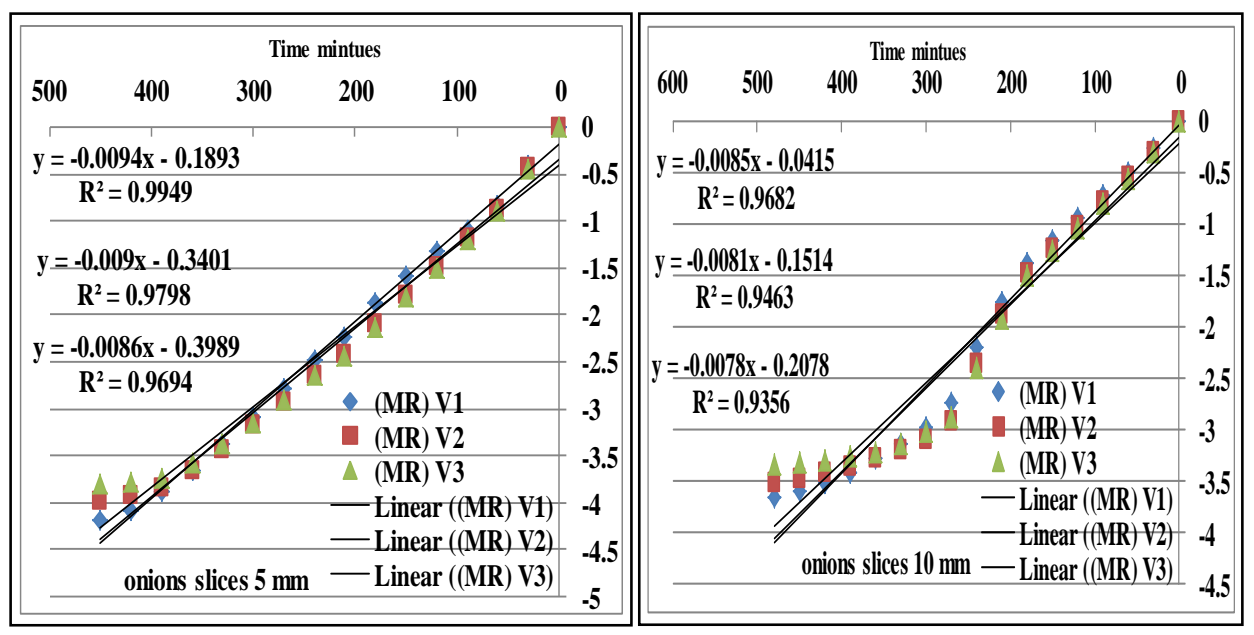

Fig. (9). Experimental logarithmic moisture ratio (MR) in function drying time for drying red onions slices 5 \& $10 \mathrm{~mm}$.

Table (5):-Moisture diffusivity for red onions slices at various speeds and drying temperature.

\begin{tabular}{|c|c|c|c|}
\hline Air speed & Thickness & Average Temp. & Diffusivity coefficient (Deff) $\mathrm{m}^{2} / \mathrm{s}$ \\
\hline \multirow{2}{*}{$0.4 \mathrm{~m} / \mathrm{s}$} & $5 \mathrm{~mm}$ & \multirow{2}{*}{43.81} & $1.59 \times 10^{-9}$ \\
\hline & $10 \mathrm{~mm}$ & & $5.72 \times 10^{-9}$ \\
\hline \multirow{2}{*}{$0.5 \mathrm{~m} / \mathrm{s}$} & $5 \mathrm{~mm}$ & \multirow{2}{*}{42.37} & $1.52 \times 10^{-9}$ \\
\hline & $10 \mathrm{~mm}$ & & $5.51 \times 10^{-9}$ \\
\hline \multirow{2}{*}{$0.6 \mathrm{~m} / \mathrm{s}$} & $5 \mathrm{~mm}$ & \multirow{2}{*}{40.82} & $1.46 \times 10^{-9}$ \\
\hline & $10 \mathrm{~mm}$ & & $5.25 \times 10^{-9}$ \\
\hline
\end{tabular}

drying temperature raised, the higher the drying temperature, the greater the rate of moisture diffusion. This phenomenon can be attributed to the increase of the vapor's pressure inside the samples, which would lead to the rapid movement of water at elevated drying temperatures (Shi et al., 2013).

\section{Computation of activation energy (Ea):-}

The activation energy (Ea) is a measure of the effect on the diffusion coefficient, and can be obtained from experimental data of the effective diffusivity. Figure 7 presents a plot of the logarithm of $D_{\text {eff }}$ versses of The diffusivity constant $\left(\mathrm{D}_{\mathrm{o}}\right)$ and activation energy $(\mathrm{Ea})$ calculated from the linear regression. The $\mathrm{D}_{\mathrm{o}}$ were $\left(3.76 \times 10^{-9} \& 1.35 \times 10^{-9}\right)$ and Ea were $(21.33 \& 19.14 \mathrm{~kJ} / \mathrm{mol})$ of red onions slices $5 \& 10 \mathrm{~mm}$. The values of the activation energy lie from 12.7 to $110 \mathrm{~kJ} / \mathrm{mol}$ for most food materials (Zogzas 1996). The relationship between the activation energy and onions 




Fig. (10). Variation of effective diffusivity as function of temperature for red onions slices $5 \& 10 \mathrm{~mm}$.

thickness was found by regression analysis. The results indicated that the power equation can predict Ea based on the thickness. In the present study, the activation energy of red onions slices $10 \mathrm{~mm}$ was slightly lower, probably because the higher amounts of water were obtained during the bitterness elimination processing, and caused the bounded water to be relatively weaker than red onions slices $5 \mathrm{~mm}$ (Qing-An Zhang et al 2016).

\section{Rehydration Characteristics:-}

The rehydration ratio of dried red onions slices is presented in table 8 . The rehydration ratio and coefficient of rehydration were calculated to return to the base block of the dried red onions. Higher rehydration ratio indicates better product. The rehydration ratio ranged from 2.15 to $2.58 \%$ for onion slices $5 \mathrm{~mm}$ while it were ranged from 1.97 to $2.36 \%$ for onion slices $10 \mathrm{~mm}$ for different air flow. The slices were having greater rehydration ratio was combined to air speed $0.5 \mathrm{~m} / \mathrm{s}$ and high temperature compared with others sample dried. At lower air speed and high Temperature plant cells are less vandalized, so that the material is capable of more absorption of water (Apar et al 2009). 
PROCESS ENGINEERING

Table (6):- Rehydration Characteristics of onions slices at various air speed rates.

\begin{tabular}{|c|c|c|c|}
\hline Air speed & Thickness & RR & COR \\
\hline \multirow{3}{*}{$0.4 \mathrm{~m} / \mathrm{s}$} & $5 \mathrm{~mm}$ & 2.58 & 0.344 \\
\cline { 2 - 4 } & $10 \mathrm{~mm}$ & 2.36 & 0.337 \\
\hline \multirow{3}{*}{$0.5 \mathrm{~m} / \mathrm{s}$} & $5 \mathrm{~mm}$ & 2.44 & 0.333 \\
\cline { 2 - 4 } & $10 \mathrm{~mm}$ & 2.22 & 0.325 \\
\hline \multirow{2}{*}{$0.6 \mathrm{~m} / \mathrm{s}$} & $5 \mathrm{~mm}$ & 2.35 & 0.328 \\
\cline { 2 - 4 } & $10 \mathrm{~mm}$ & 2.16 & 0.327 \\
\hline \multirow{2}{*}{ Sun dry } & $5 \mathrm{~mm}$ & 2.15 & 0.311 \\
\cline { 2 - 4 } & $10 \mathrm{~mm}$ & 1.97 & 0.317 \\
\hline
\end{tabular}

\section{Payback analysis:-}

The payback period is calculated as the time required for the investment cost to equal the return. In our case the payback period (1.84 years) extend to return the investment cost because the small quantity produced by the dryer due to its small size. The life of the dryer ( 25 years), so the dryer will dry product free of cost for almost its entire life period.

$$
\text { Payback period }=\frac{3000}{1628}=1.84 \text { years. }
$$

\section{CONCLUSION}

1- The average daily dryer efficieny arrived to $16.98,19.04$ and $22.43 \%$ for air speed $0.4,0.5$ and $0.6 \mathrm{~m} / \mathrm{s}$ respectiviely.

2- page, and Modified page II was selected as a suitable model to drying red onions slices ( $5 \& 10 \mathrm{~mm}$ ) respectiviely.

3- The Effective moisture diffusivity varied from $1.46 \times 10-9$ to $1.59 \times 10$ $9 \mathrm{~m}^{2} / \mathrm{s}$ and $5.25 \times 10-9$ to $5.72 \times 10-9 \mathrm{~m}^{2} / \mathrm{s}$ for red onions slices $(5 \& 10$ $\mathrm{mm})$ respectiviely.

4- The activation energy value of $21.33 \mathrm{~kJ} / \mathrm{mol}$ and $19.14 \mathrm{~kJ} / \mathrm{mol}$ for red onions slices $5 \& 10 \mathrm{~mm}$ ) respectively.

5- The payback period for is dryer incubator were 1.84 years. 
PROCESS ENGINEERING

6- The rehydration ratio of dried red onions slices $5 \mathrm{~mm}$ ranged from 2.15 to $2.58 \%$ while it was ranged from 1.97 to $2.36 \%$ for $10 \mathrm{~mm}$ respectively.

\section{REFERENCES}

AOAC. (2005). Association of Official Analytical Chemists, Official Methods of Analysis (18th Ed.)International, Maryland, USA.

Akpinar, E.K., Bicer, F. and Cetinkaya, F. 2006. Modelling of thin layer drying of parsley leaves in a convective dryer and under open sun. J. Food Eng. 75, 308-315.

Apar, D., Demirhan, E. and Dadali, G.(2009):Rehydration kinetics of microwave-dried okras as affected by drying conditions. Journal of Food Processing and Preservation,33 (5):618-634.

Bruce, D.M., (1985). Exposed layer barley drying, three models fitted to new data up to 150 oC. J. Agric. Eng. Res., 32: 337-347.

Boughali,A., Benmoussa,H., Bouchekima, B., Mennouche,D., Bouguettaia,H.and Bechki,D.(2009). Crop drying by indirect active hybrid solar - Electrical dryer in the eastern Algerian Septentrional Sahara: Solar Energy 83 (2009) 2223-2232. Available online at www.sciencedirect.com.

Crank J. (1975): Mathematics of diffusions. Oxford University Press, London.

Diamante air drying of sweet potato slices. Int. J. Food Sci. Technol., 26: 99., L.M. and Munro, P.A. (1991). Mathematical modeling of hot.

El Mesery H. S.and Mwithga G.(2012). The drying of onion slices in two types of hot-air convective dryers. African Journal of Agricultural Research Vol. 7(30), pp. 4284-4296, 7 August, 2012 Available online at http://www. academicjournals.org /AJAR DOI:10.5897/AJAR11. 2065. 
Henderson, S.M. \& Pabis,S. (1961).Grain drying theory. II. Temperature effects on drying coefficients. J.Agric. Eng. Res., 6: 169-174.

Kutscher, C.F., Christensen, C., Barker, G., 1993. Unglazed transpired

solar collectors: heat loss theory. ASME Journal of Solar Engineering 115 (3), 182-188.

Kolawole, O. Falade, Emmanuel, S. Abbo, 2007. Air drying and characteristics of date palm fruits. Journal of Food Engineering 79, 724-730.

Lyes B.and Azeddine B. (2003) Design and simulation of a solar dryer for agriculture products. Journal of Food Engineering 59 (2003) 259266. www.elsevier.com/locate/jfoodeng.

Maskan, M. 2001. Drying, shrinking and rehydration characteristic of kiwi fruit during hot air and microwave drying. J. Food Eng. 48, 177-182.

Mahmoud Y., Diaeldin A. and Assem Z.E. Kinetics and mathematical modeling of infrared thin-layer drying of garlic slices. Saudi Journal of Biological Sciences 25 (2018) 332-338. www.sciencedirect.com

Midilli, A., Kucuk, H., 2003. Mathematical modelling of thin layer drying of pistachio by using solar energy. Energ. Convers. Manage. 44, 1111-1122. http://dx.doi. org/10.1016/S0196-8904 (02) 00099-7.

Midilli, A., 2001. Determination of pistachio drying behaviour and conditions in asolar drying system. Int. J. Energy Res. 25, 715-725. http://dx.doi.org/10.1002/er.715.

Motaa, C.L. Lucianoa, C. A. Diasa, M.J. Barrocab and Guinéa,R.P.F. 2010.Convective drying of onion: Kinetics and nutritional 
PROCESS ENGINEERING

evaluation. ScienceDirectfood and bioproducts processing $88115-$ 123. www.elsevier.com/locate/fbp

Neufville, R.(1990). Applied Systems Analysis. McGraw-Hill Publishing Company, New York, USA

Page, G.E.,(1949). Factors influencing the maximum rates of air drying shelled corn in thin layers. M.S. Thesis, Department of Mechanical Engineering, Purdue University, purdue, USA.

Pankaj,B.P. and Sharma, G.P.(2006) Effective Moisture Diffusivity of Onion Slices undergoing Infrared Convective Drying Biosystems Engineering (2006) 93 (3), 285-291. www science direct.com.

Qing-An Zhang, Yun Song, Xi Wang, Wu-Qi Zhao \& Xue-Hui Fan (2016) Mathematical modeling of debittered apricot (Prunus armeniaca L.) kernels during thin-layer drying Journal of Food, 14:4, 509-517, DOI: 10.1080/19476337.2015.1136843: https://doi.org/10.1080/19476337.2015.1136843.

Sarsavadia, P.N. (2006) Development of a solar-assisted dryer and evaluation of energy requirement for the drying of onion. Science $\begin{array}{lllll}\text { direct Renewable } & \text { Energy } & 32 & \text { (2007) 2529-2547 }\end{array}$ .www.elsevier.com/locate/renene.

Shi, Q., Zheng, Y., \& Zhao, Y. (2013). Mathematical modeling on thin layer heat pump drying of yacon (Smallanthus sonchifolius) slices. Energy Conversion and Manage, 71, 208-216.

Tabaei, H., Ameri, M., (2015). Improving the effectiveness of a photovoltaic water pumping system by using booster reflector and cooling array surface by a film of water. IJST Trans. Mech. Eng. 39 (M1), 51-60. 
White, G.M., I.J. Ross and Ponelert, R. (1981). Fully exposed drying of popcorn. Tran. ASAE, 24: 466-468.

Zogzas N.P., Marulis Z.B., Mariinos-Kourisd (1996):Moisture diffusivity data compilation in foodstuffs. Drying Technology, 14: 2225-2253.

الملخص العربي



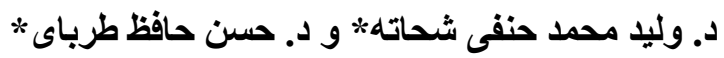

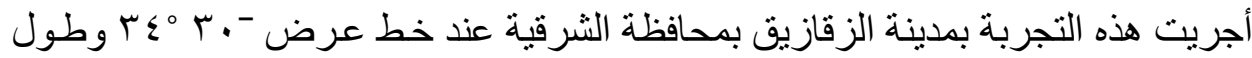

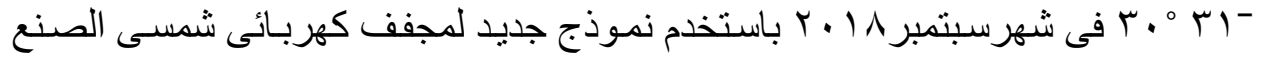

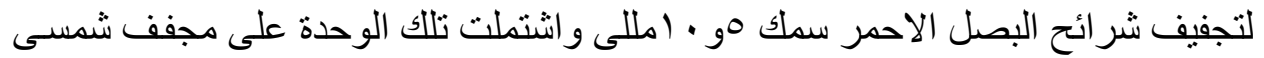

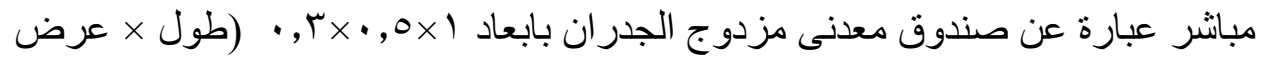

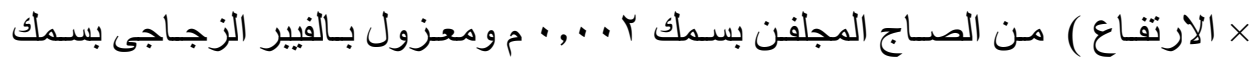







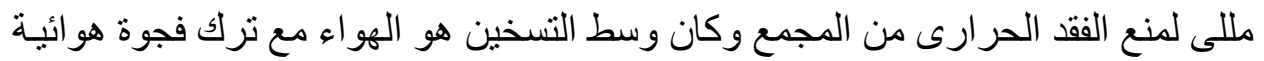

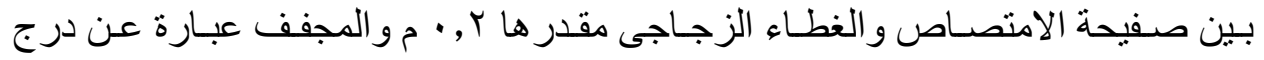

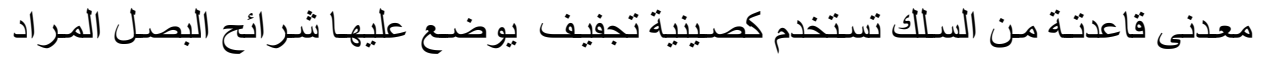

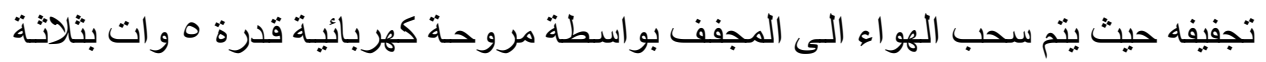

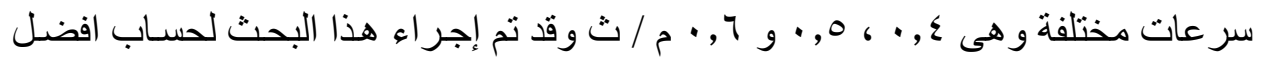

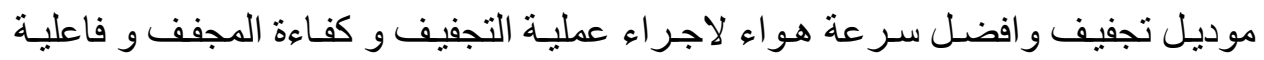
الانتشار الرطوبى و طاقة التفعيل ونسبة الاماهة. و قد تبين من النتائج المتحصل عليها كل مما يأتي :

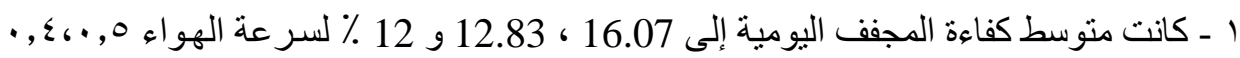

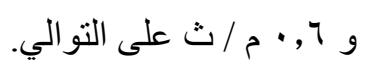

r- كانت معادلة Modified Page II, Page افضل نموذج لـحاكاة تجفيف شر ائح البصل ه



*مدرس بقسم الهندسة الزراعية ـ كلية الزراعة والموارد الطبيعية - جامعة اسوان. 


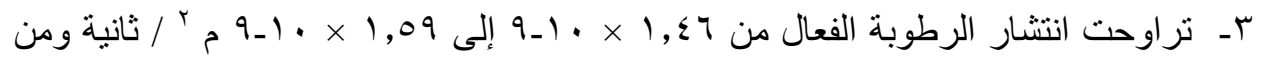


التو الي.

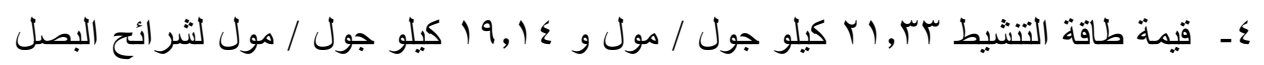

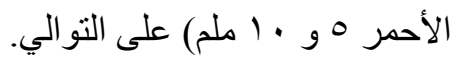
ـ فترة الاستر داد للمجف كانت ع ^ر ا سنة.

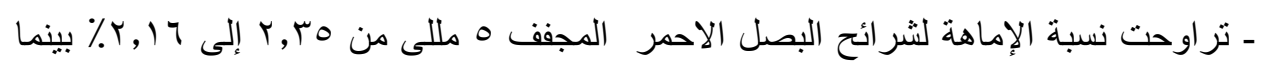

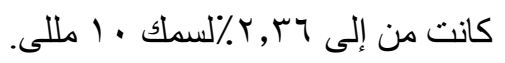

